\title{
Sinkronisasi Content E-learning Terdistribusi Berbasis Model Komunikasi Indirect Menggunakan Sistem Publish-Subscribe
}

\author{
Sufrendo Saputra, Royyana Muslim Ijtihadie, dan Waskitho Wibisono \\ (ITS) \\ Jl. Arief Rahman Hakim, Surabaya 60111 Indonesia \\ e-mail: roy@if.its.ac.id
}

Jurusan Teknik Informatika, Fakultas Teknologi dan Informasi, Institut Teknologi Sepuluh Nopember

\begin{abstract}
Abstrak-Sinkronisasi content antar e-learning memungkinkan beberapa e-learning memiliki content yang sama secara konsisten. Perubahan content pada salah satu e-learning akan membuat sistem memastikan e-learning lain mengetahui perubahan tersebut. Model komunikasi yang memungkinkan adanya sinkronisasi ini merupakan komunikasi indirect berbasis publish-subscribe. Setiap e-learning memiliki content-nya masingmasing yang secara otomatis akan di-publish oleh sistem. Elearning lain yang tergabung dalam sistem sinkronisasi kemudian dapat memilih content mana yang ingin di-subscribe. Jika terdapat perubahan pada sebuah content, dan content tersebut memiliki subscriber, maka sistem akan memberitahu subscriber bahwa telah terjadi perubahan pada content. Teknologi utama yang digunakan dalam sistem ini adalah Moodle, PHP, dan Java. Moodle sebagai modul yang digunakan untuk mensimulasikan $e$ learning. PHP dan Java sebagai framework dari sistem sinkronisasi. Model komunikasi yang digunakan merupakan komunikasi indirect berbasis publish-subscribe. Model komunikasi ini menempatkan sebuah perantara bagi komunikasi antar e-learning.
\end{abstract}

Kata kunci-e-learning, java, publish-subscribe, sinkronisasi

\section{PENDAHULUAN}

$\mathrm{S}$ AAT ini kita hidup di zaman di mana sistem terdistribusi sudah menjadi bagian dari kehidupan kita sehari-hari. Sistem terdistribusi sendiri didefinisikan sebagai sebuah sistem di mana komponen-komponen yang berlokasi pada sebuah jaringan komputer saling berkomunikasi dan mengoordinasikan aksi mereka dengan cara bertukar pesan. Salah satu contoh aplikasi modern dari sistem terdistribusi dalam bidang pendidikan adalah e-learning atau sistem pembelajaran elektronik.

George Colouris dalam "Distributed Systems: Concepts and Design" menyebutkan bahwa dalam sistem terdistribusi terdapat tiga tipe paradigma komunikasi antar entitas [1]. Salah satunya adalah indirect communication atau komunikasi tak langsung. Sifat khusus dari indirect communication adalah penggunaan perantara dalam pengiriman pesan. Penggunaan perantara ini melahirkan dua karakteristik penting yaitu space uncoupling dan time uncoupling. Patrick Th. Eugster dalam "The Many Faces of Publish/Subscibe" bahkan menyebutkan bahwa sistem publish-subscribe, salah satu model dari paradigma indirect communication, memiliki satu karakteristik tambahan yaitu syncronization uncoupling [2].

Sifat-sifat yang dimiliki oleh paradigma indirect communication dapat dimanfaatkan untuk sinkronisasi dalam sistem terdistribusi. Kasus sinkronisasi yang diangkat dalam Tugas Akhir ini adalah sinkronisasi content antar e-learning.

Salah satu alasan mengapa sinkronisasi content antar $e$ learning dirasa perlu adalah untuk menyeragamkan kualitas content. Materi pembelajaran yang disusun oleh para ahli yang sudah terpercaya di bidangnya tentu akan dirasa lebih berkualitas. Dengan adanya sikronisasi, bahan ajar tersebut nantinya dapat digunakan pada platform e-learning milik instansi lain sebagai upaya untuk meningkatkan kualitas pembelajaran. Tenaga pengajar tidak perlu dipusingkan dengan penyusunan materi dan dapat fokus pada yang sudah ada.

Sinkronisasi dilakukan menggunakan sistem publishsubscribe, sebagai salah satu model dari paradigma indirect communication, karena beberapa sifatnya yang telah disebutkan di atas. Alasan lainnya karena model direct communication dirasa bukan menjadi prioritas dalam kasus sinkronisasi content. Alur pengiriman data dalam proses sinkronisasi tidak perlu dibebankan kepada perangkat $e$ learning melainkan cukup difokuskan pada satu pihak yang berfungsi sebagai event router.

Sebagai batasan, platform e-learning yang digunakan pada Tugas Akhir ini adalah Moodle, dan sinkronisasi yang dimaksudkan meliputi activity/resource pada Moodle yaitu, page dan file.

'Makalah ini akan membahas mengenai perancangan sistem sinkronisasi content e-learning terdistribusi berbasis model komunikasi indirect menggunakan sistem publish-subscribe.

\section{II.TINJAUAN PUSTAKA}

\section{A. Indirect Communication}

Indirect communication didefinisikan sebagai komunikasi antar entitas dalam sebuah sistem terdistribusi melalui sebuah perantara tanpa ada hubungan langsung antara pengirim dan penerima. Sifat spesifik perantara berbeda-beda dari satu pendekatan ke pendekatan lainnya. Sebagai tambahan, sifat spesifik pengirim dan penerima antar sistem juga dapat memiliki perbedaan yang signifikan[1]. 
Penggunaan perantara dalam paradigma indirect communication melahirkan tiga karakteristik penting yaitu space uncoupling, time uncoupling, dan synchronization uncoupling.

\section{B. Sistem Publish-Subscribe}

Sistem publish-subscribe merupakan sistem di mana publisher memublikasikan event terstruktur kepada event service dan subscriber menyatakan ketertarikan terhadap event tertentu melalui subscription yang dapat berupa pola sembarang dari event terstruktur tersebut. Tugas dari sistem publish-subscribe adalah untuk mencocokkan subscription dengan event yang dipublikasikan dan menjamin pengiriman notifikasi event yang benar. Sebuah event bisa saja dikirimkan ke banyak subscriber, dan karena itulah pada dasarnya publishsubscribe merupakan sebuah paradigma komunikasi one-tomany.

\section{E-learning}

E-learning mengacu pada penggunaan internet atau teknologi nirkabel untuk menyediakan berbagai macam solusi pelatihan. Dalam lingkungan e-learning, murid berinteraksi dengan bahan ajar, instruktur (guru dan/atau dosen) dan murid (mahasiswa) lain dari berbagai lokasi dan seringkali pada waktu yang berbeda-beda menggunakan teknologi jaringan komputer. Pada dasarnya, e-learning menawarkan fleksibilitas yang tinggi terhadap kapan dan bagaimana proses pembelajaran berlangsung.

\section{Moodle}

Moodle merupakan Course Management System (CMS) yang dikembangkan oleh Martin Dougiamas. Nama Moodle merupakan akronim dari Modular Object-Oriented Dynamic Learning Environment. Beberapa kelebihan yang dimiliki Moodle dibandingkan dengan CMS lainnya antara lain sifatnya yang free dan open source, desain yang berfilosofi pada pendidikan, serta memiliki komunitas yang besar dan aktif dalam mengembangkan perbaikan dan fitur-fitur baru [3]. Sebuah course dalam Moodle dapat terdiri atas bermacammacam komponen atau yang biasa disebut dengan activity/resource.

Activity/resource merupakan nama umum untuk sekumpulan fitur dalam sebuah course Moodle. Anda dapat menbayangkan activity sebagai kumpulan modul yang melengkapi sebuah course. Biasanya activity merupakan sesuatu yang akan dilakukan murid dimana mereka berinteraksi dengan murid lain atau dengan sang instruktur. Ada berbagai macam tipe activity dalam instalasi standar Moodle yang dapat dilihat pada menu add an activity. Dua jenis activity yang akan coba disinkronisasikan dalam Tugas Akhir ini adalah page dan file.

\section{E. Java}

Java adalah bahasa pemrograman berorientasi objek yang dikembangkan oleh Sun Microsystems sejak tahun 1991. Bahasa ini dikembangkan dengan model yang mirip dengan bahasa $\mathrm{C}++$ dan Smalltalk, namun dirancang agar lebih mudah dipakai dan platform independent, yaitu dapat dijalankan di berbagai jenis sistem operasi dan arsitektur komputer.

Kompiler dan interpreter untuk program Java berbentuk JDK
(Java Development Kit) yang diproduksi oleh Sun Microsystems. Interpreter untuk program Java sering juga disebut Java Runtime atau JVM (Java Virtual Machine). Interpreter Java tanpa kompilernya disebut JRE (Java Runtime Environment). Untuk mengembangkan program Java dibutuhkan JDK, sementara untuk menjalankan program atau aplikasi berbasis Java cukup dengan JRE saja.

\section{F. Event router Avis}

Avis merupakan sebuah event router. Avis menyediakan layanan event routing berbasis publish-subscribe yang menerapkan implementasi Elvin hasil karya Mantara Software. Beberapa kelebihan event router antara lain pengiriman pesan dengan format yang fleksibel dan dapat dijalankan pada platform manapun yang mendukung Java 5 ke atas.

\section{III.DESAIN DAN IMPLEMENTASI}

\section{A. Arsitektur Sistem}

Sistem terdiri atas beberapa mesin yang menjalankan Moodle. Mesin ini akan saling terhubung dengan sebuah server event router. Pada tiap mesin akan terdapat 2 buah program Java yang bernama Sender.java dan Receiver.java. Kedua program ini yang akan berkomunikasi dengan event router untuk menjalankan proses sinkronisasi. Gambaran besar arsitektur sistem dapat dilihat pada Gambar 1.

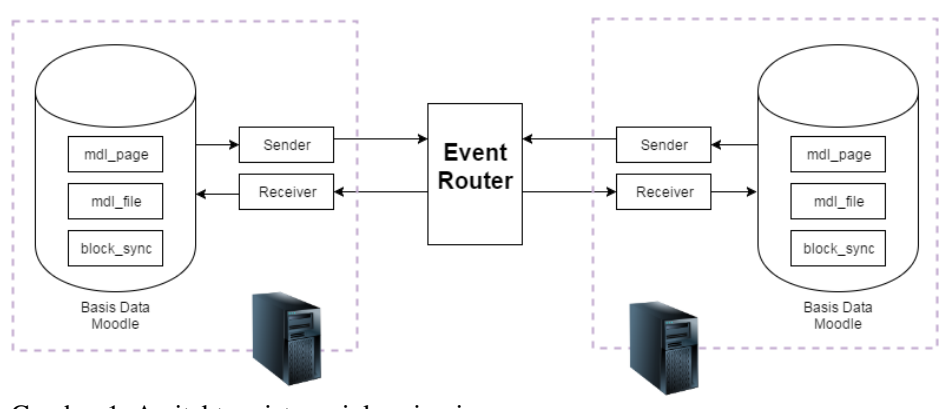

Gambar 1. Arsitektur sistem sinkronisasi.

Program sender secara berkala akan melakukan pengecekan pada basis data Moodle untuk menetapkan apakah telah terjadi pembaruan. Untuk setiap pembaruan yang terdeteksi, Sender akan mengirimkannya kepada event router. Event router kemudian akan meneruskan data dari sender kepada receiver milik entitas yang menjadi subscriber untuk content tersebut. Begitu diterima, receiver akan melakukan pembaruan pada basis data Moodle. Tiap entitas dapat menjadi publisher sekaligus subscriber.

Komunikasi antar entitas berlangsung secara tidak langsung (indirect communication). Dalam arti sender milik sebuah entitas tidak pernah berkomunikasi secara langsung dengan receiver milik entitas lain. Komunikasi ini ditangani oleh event router Avis.

Model subscription yang digunakan pada sistem ini adalah content-based subscription. Di sisi publisher, semua pesan dari Sender akan diteruskan ke event router. Sender tidak mengetahui siapa saja yang akan mendapat pesan tersebut. Sedangkan di sisi subscriber, Receiver terus menerus mendengarkan pesan dari event router. 


\section{B. Proses Sinkronisasi}

Proses ini dapat dibagi menjadi beberapa tahap sebagai berikut: proses subscribe, menentukan pembaruan pada content milik publisher, publisher mengirimkan pembaruan kepada event router, event router menotifikasi subscriber mengenai adanya pembaruan sekaligus mengirimkan isi pembaruan, subscriber menerapkan pembaruan.

Subscriber pertama kali akan memilih content apa yang akan di-subscribe. Informasi subscription akan disimpan dalam tabel block_sync. Receiver akan menggunakan informasi dalam tabel tersebut untuk menghasilkan subscription expression. Dari sana event router akan menotifikasi receiver jika terdapat pesan yang cocok dengan subscription expression yang dimiliki receiver. Informasi subsciption yang digunakan Receiver untuk menghasilkan subscription expression berupa indeks content dan status subscription.

Indeks content merupakan id unik yang diberikan kepada tiap content Moodle yang tergabung dalam sistem. Setiap entitas Moodle yang tergabung dalam sistem mengenali id ini. Sedangkan status subscription menentukan content mana yang di-subscribe oleh Moodle. Saat terjadi pembaruan pada content milik publisher, sender akan mengirim pesan kepada event router. Pesan tersebut berupa informasi content yang mengalami pembaruan beserta dengan isi pembaruan. Informasi content yang dikirim berupa indeks content yang dapat dikenali oleh receiver.

Event router kemudian menotifikasi receiver. Jika event yang terjadi (pembaruan pada content yang di-subscribe) sesuai dengan subscription expression yang ada pada Receiver, maka receiver akan menerima dan menerapkan pembaruan ke dalam basis data Moodle.

\section{Metadata}

Metadata meliputi data pendukung yang dikirimkan bersama dengan notifikasi kepada event router. Data ini bertujuan agar nantinya penerima notifikasi dapat mengenali notifikasi yang didapat dan menerapkan data pembaruan dalam basis datanya secara akurat. Salah satu metadata yang digunakan adalah data dari tabel block_sync untuk mengenali tiap course yang ada pada sistem sinkronisasi. Struktur dari tabel block_sync dapat dilihat pada Tabel 1.

Tabel 1.

Struktur tabel block_sync

\begin{tabular}{ll}
\hline Data & Penjelasan \\
\hline tid & Merujuk pada id course pada tabel \\
& mdl_course \\
& Merupakan id unik yang diberikan untuk \\
& semua course Moodle yang tergabung \\
& dalam sistem \\
& Pemilik atau pembuat course \\
owner & Nama course \\
coursename & Status subscribtion (0=pemilik asli \\
status & course; $1=$ bukan pemilik asli course, tidak \\
& men-subscribe; 2=bukan pemilik asli \\
& course, men-subscribe, 3=pemilik asli \\
& course, course ini baru saja dibuat/belum \\
& tersinkronisasi dengan \\
& mdl_block_sync lain)
\end{tabular}

Selain data dari tabel di atas, publisher juga mengirimkan metadata yang berisi informasi content apa yang diperbarui. Data ini dikirimkan dalam dua nilai yang bernama section dan modul. Cara mendapatkan kedua nilai ini ditunjukkan melalui Gambar 2.

Pada Gambar 2, misalkan terjadi pembaruan pada content bernama "Pengantar $\mathrm{C}++$ ", maka publisher akan memberikan notifkasi bahwa telah terjadi perubahan untuk content dengan indeks section $=1$ dan modul $=1$.

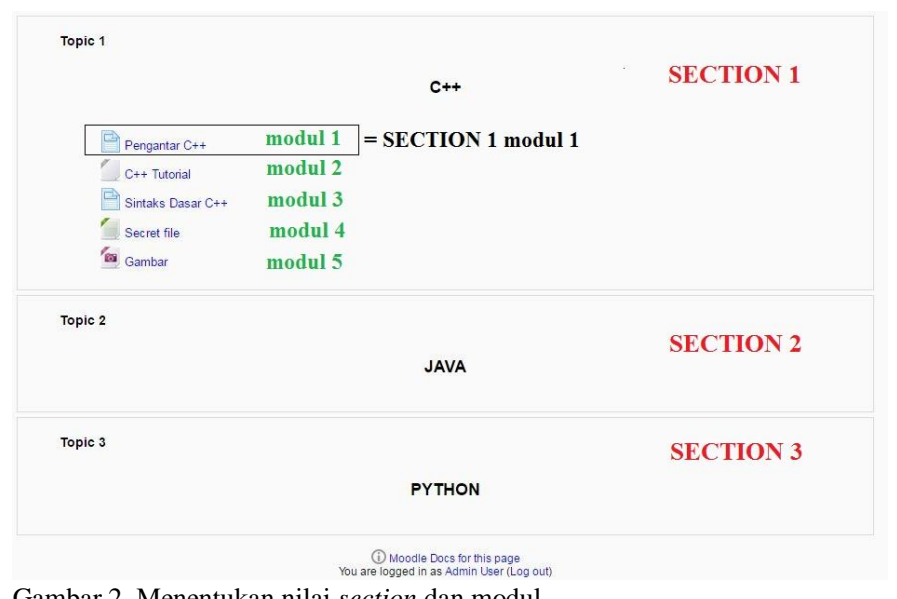

Gambar 2. Menentukan nilai section dan modul.

\section{UJI COBA DAN EVALUASI}

Pada bab ini akan dijelaskan uji coba yang dilakukan pada aplikasi yang telah dikerjakan serta analisa dari uji coba yang telah dilakukan. Pembahasan pengujian meliputi lingkungan uji coba, skenario uji coba yang meliputi uji kebenaran dan uji kinerja serta analisa setiap pengujian.

\section{A. Lingkungan Uji Coba}

Lingkungan uji coba menjelaskan lingkungan yang digunakan untuk menguji implementasi pembuatan sistem. Lingkungan uji coba meliputi perangkat keras dan perangkat lunak yang digambarkan sebagai berikut.
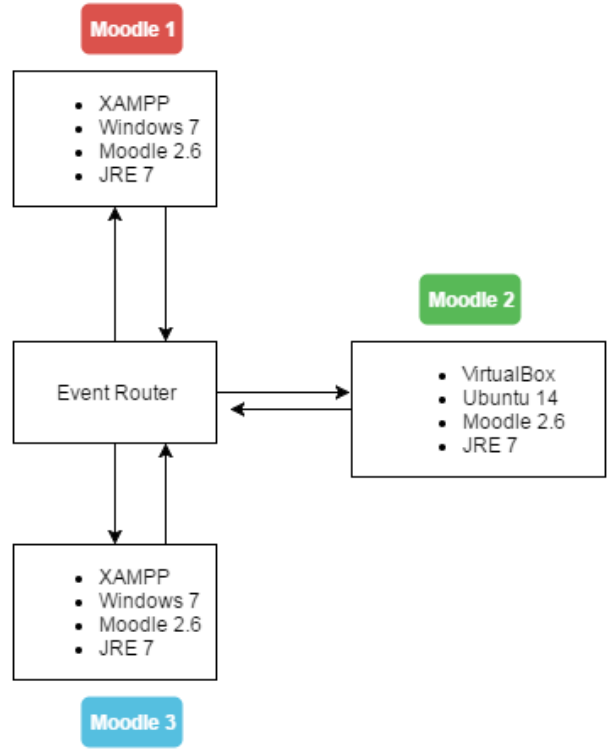

(a) 


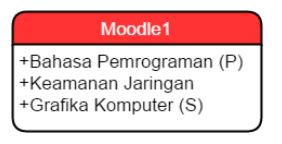

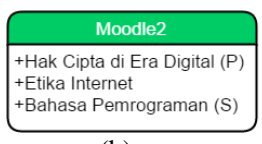

(b)

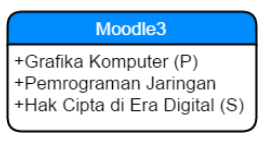
Hak Cipta di Era Digital (S)

Gambar 3. Arsitektur uji coba (a) dan struktur course yang dimiliki tiap Moodle (b).

Pada arsitektur di atas terdapat dua Moodle yang dijalankan melalui virtual host XAMPP dan satu Moodle melalui virtual machine VirtualBox. Semua mesin menggunakan instalasi Moodle versi 2.6 dan Java Runtime Environment (JRE) 7.

\section{B. Skenario 1}

Uji coba ini dilakukan untuk menguji apakah fungsionalitas sistem telah diimplementasikan dengan benar dan berjalan sebagaimana mestinya. Uji coba akan didasarkan pada salah satu skenario untuk menguji kesesuaian dan kinerja sistem sinkronisasi.

Pengujian fungsionalitas dilakukan antara Moodle1 dan Moodle2. Moodle2 men-subscribe course Bahasa Pemrograman milik Moodle1. Pada Moodle1 akan dilakukann perubahan pada salah satu file yang bernama gambar1.jpg. Gambar ini akan diganti dengan gambar baru dan ketika proses sinkronisasi berjalan, maka file gambar1,jpg pada Moodle2 akan ikut berubah.

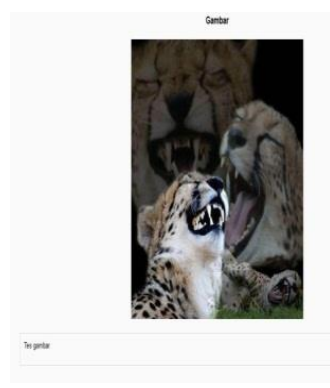

(a)

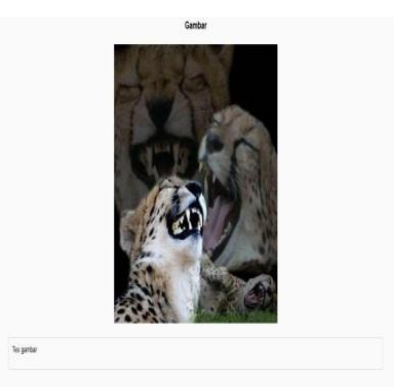

(b)
Gambar 4. Perbandingan gambar1.jpg pada Moodle1 (a) dan Moodle2 (b) sebelum dilakukan perubahan

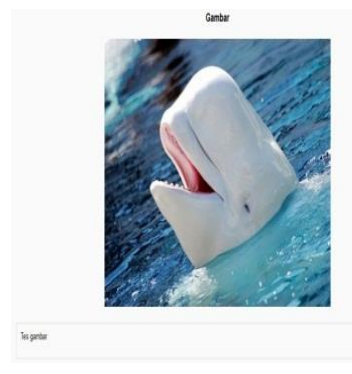

(a)

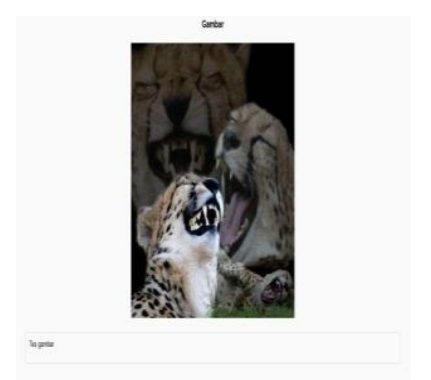

(b)
Gambar 5. Perbandingan gambar1.jpg pada Moodle1 (a) dan Moodle2 (b) ketika dilakukan perubahan pada Moodle1

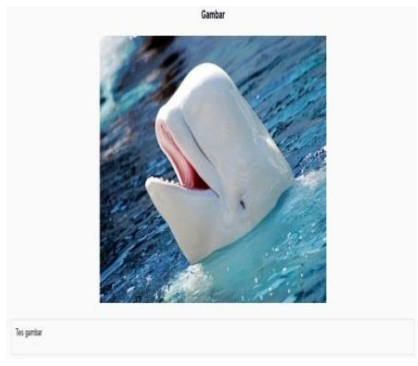

(a)

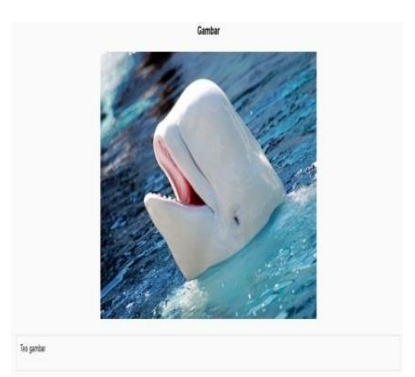

(b)
Gambar 6. Perbandingan gambar1.jpg pada Moodle1 (a) dan Moodle2 (b) ketika proses sinkronisasi telah dilakukan.

\section{Skenario 2}

Pada skenario 2 akan dilakukan uji performa untuk mengetahui besaran data dan delay dari proses pengiriman data dari publisher hingga sampai ke subscriber.

Tabel 5.

Uji performa pengiriman data.

\begin{tabular}{llll}
\hline \hline $\begin{array}{c}\text { Content Yang } \\
\text { Mengalami Pembarua }\end{array}$ & Tipe Data & \multicolumn{1}{c}{$\begin{array}{c}\text { Ukuran Data } \\
\text { (byte })\end{array}$} & $\begin{array}{c}\text { Rata-Rata } \\
\text { Delay } \\
\text { (byte/ms) }\end{array}$ \\
\hline $\begin{array}{l}\text { Pembaruan "Pengantar } \\
\text { C++" }\end{array}$ & teks & 1716 & 602.57 \\
$\begin{array}{l}\text { Pembaruan } \\
\text { "Helloc++.cc" }\end{array}$ & teks & 214000 & 485.21 \\
$\begin{array}{l}\text { Gambar1 } \\
\text { Gambar2 }\end{array}$ & gambar & 581000 & 441.85 \\
\hline
\end{tabular}

\section{V.KESIMPULAN}

Dari hasil uji coba yang telah dilakukan terhadap fungsifungsi dan kinerja sistem, kesimpulannya adalah sebagai berikut:

1. Sinkronisasi content antar LMS Moodle mampu dijembatani oleh metode komunikasi publish subscribe dengan menggunakan event routing.

2. Dari hasil pengujian pada bab uji coba dan evaluasi, didapat kecepatan dan ukuran data yang dikirimkan dari beberapa kondisi yang berbeda yang telah ditentukan sebelumnya.

\section{DAFTAR PUSTAKA}

[1] G. Coulouris et al., Distributed Systems: Concept and Design, 5th ed. Boston, MA: Addison-Wesley, 1998.

[2] P. Th. Eugster et al. (2003, June). "The Many Faces of Publish Subscribe." ACM Computing Surveys. [Online]. 35(2), pp. 114-131. Available: http://dl.acm.org/citation.cfm?id=857078 [Feb. 28, 2014].

[3] J. Cole and H. Foster, Using Moodle: Teaching with the Popular Open Source Management System, 2nd ed. California: O’Reilly, 2007. 